\title{
A QUESTIONNAIRE FOR ASSESSING FEAR OF RADIOTHERAPY IN ONCOLOGY PATIENTS
}

Marija Zivkovic Radojevic ${ }^{1}$, Marko Folic ${ }^{1,2}$, Slobodan Jankovic ${ }^{1,2}$

${ }^{1}$ Faculty of Medical Sciences, University of Kragujevac, Kragujevac, Serbia

${ }^{2}$ Clinical Pharmacology Department, Clinical Centre Kragujevac, Kragujevac, Serbia

\author{
UPITNIK ZA PROCENU NIVOA STRAHA OD RADIOTERAPIJE \\ KOD ONKOLOŠKIH PACIJENATA \\ Marija Živković Radojević ${ }^{1}$, Marko Folić ${ }^{1,2}$, Slobodan Jankovic ${ }^{1,2}$ \\ ${ }^{1}$ Fakultet medicinskih nauka, Univerzitet u Kragujevcu, Kragujevac, Srbija \\ ${ }^{2}$ Služba za kliničku farmakologiju, Klinički centar Kragujevac, Kragujevac, Srbija
}

The study was conducted in Clinical Centre Kragujevac in the Centre for Oncology and Radiology, Department of radiotherapy.

\begin{abstract}
Radiotherapy is a frequently prescribed and highly effective form of treatment of oncology patients. However, many patients feel rational or irrational fear of the application of radiotherapy, which may provoke mental and physical stress, anxiety, growing anger and hostility, thus reducing quality of life. The aim of this study was to develop, reliability test and validate a questionnaire for assessing the level of fear of radiotherapy in oncology patients.

We performed a prospective qualitative study based on the development, validation and reliability testing of the questionnaire developed for assessing radiotherapy-caused fear in oncology patients treated in the Centre for Oncology and Radiology, Department of Radiotherapy, Clinical Centre Kragujevac.

The study included 154 patients and the final version of the questionnaire integrated 15 questions. After the elimination of inappropriate questions the Cronbach coefficient $\alpha$ was 0.946. The questionnaire consists of two factors which represent $57.423 \%$ and $6.925 \%$, making a total of $64.348 \%$ of the variance of the questionnaire.

The results of our study show that the questionnaire used is a unique, reliable and valid instrument for assessing the level of fear of radiotherapy in oncology patients the application of which will allow us to identify patients with elevated levels of fear of radiotherapy.
\end{abstract}

Keywords: radiotherapy, fear, oncology patients

\section{SAŽETAK}

Radioterapija je često propisivan $i$ veoma efikasan vid lečenja onkoloških pacijenata. Medutim, mnogi pacijenti osećaju kako racionalan, tako i iracionalan strah od primene radioterapije, što može potencirati psihički i fizički stres, anksioznost, razvoj ljutnje, neprijateljski stav, i na taj način dodatno smanjiti kvalitet života. Cilj ovog istraživanja bazirao se na izradi, ispitivanju pouzdanosti $i$ validaciji upitnika za procenu nivoa straha od radioterapije kod onkoloških pacijenata.

Sprovedena je prospektivna, kvalitativna studija utemeljena na izradi, proveri pouzdanosti $i$ validaciji upitnika za procenu nivoa straha od radioterapije kod onkoloških pacijenata lečenih na Odeljenju radioterapije Centra za onkologiju i radiologiju Kliničkog centra Kragujevac.

U istraživanju je učestvovalo 154 ispitanika, a finalna verzija upitnika obuhvatala je ukupno 15 pitanja. Cronbachov koeficijent $\alpha$, nakon eliminacije neadekvatnih pitanja, iznosio je 0,946. Upitnik je integrisao dva faktora koji su predstavljali 57,423\% i 6,925\%, ćineći ukupno 64,348\% varijanse upitnika.

Rezultati našeg istraživanja su pokazali da se korišćeni upitnik može smatrati jedinstvenim, pouzdanim $i$ validnim instrumentom za merenje nivoa straha od radioterapije kod onkoloških pacijenata, $i$ da se njegovom primenom na relevantan način mogu identifikovati pacijenti sa prisutnim povišenim stepenom straha od radioterapije.

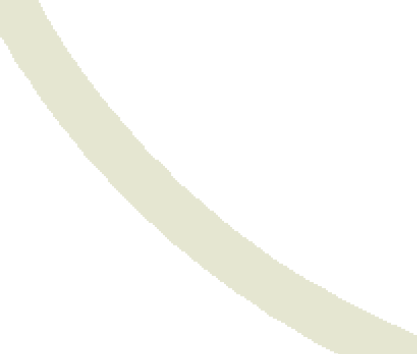

OP- oncology patients QAFRT- questionnaire for assessment fear of radiotherapy
Ključne reči: radioterapija, strah, onkološki pacijenti 


\section{INTRODUCTION}

Radiotherapy (RT) is a frequently prescribed and highly effective form of treatment of oncology patients (OPs). It may be curative or palliative. The aim of implementation of $\mathrm{RT}$ is based on the local effect on malignant cells, with the maximum preservation of the surrounding normal tissue. Although the aforementioned type of therapy is associated with a number of useful aspects of implementation and positive impacts on the health, many patients feel rational or irrational fear of the application of RT. Bad and unpleasant experiences associated with other oncology therapeutic options, such as chemotherapy and surgery, often lead to refusals to start or cancellations of RT treatment (1).

Radiotherapy may initiate mental and physical stress, anxiety, growing anger and hostility, and reduce quality of life (1-5). Moreover, changes in mental state can affect the course of the disease, and mental and physical status (1, 4-8). Oncology patients are characterized by a higher level of anxiety than patients with other diseases (1). Anxiety represents a specific mental state of increased vigilance and prudence in anticipation of unpleasant events without the presence of real danger (9). Some OPs, treated with RT, however, experience serious psychological reactions that may manifest as fear of RT, and which may significantly affect compliance. Fear is a response to real dangerous events and can be manifested by defensive reactions: fight, flight or "freezing" (9).

Many patients think that their pathology is characterized by a poor prognosis, because RT is indicated, and very often take the attitude that RT treatment is vain in their case (2). Although the effects of radiation during treatment cannot be felt, most patients have somatization symptoms of psychological discomfort caused by fear. It is interesting to note that those patients who showed a lower level of anxiety before exposure to RT are characterized by greater anxiety during and/or after RT, and vice versa (1). Patients are mostly concerned about the potential impact of RT on family life and work obligations, the occurrence of new cancers, reducing libido, sterility, the occurrence of burns, pain and scarring, etc. (10). Increases in the level of anxiety, discomfort and an intensification of thinking about the disease may be brought about by the treatment; the closed steel door in the room for radiation, the lack of windows, isolation during the radiation procedure and the size of the RT device $(1,2,11,12)$. It can be assumed that the anxiety and fear before treatment are uncertainty conditioned, while anxiety and fear during and after RT treatment are associated with concern about developing side-effects of the treatment and the possibility that they have exhausted all treatment options. Radiotherapy is easier to accept and tolerate for patients who regularly visit radiotherapists, those who possess a higher level of knowledge about RT, than patients who receive palliative therapy and those with a better "performance" status $(6,7,13-15)$.

A relatively small number of studies have addressed this issue. Analysis of the level of RT-caused anxiety in OPs is offered in earlier studies based on structured interviews with a psychiatrist, using the Mental Component Summary Scale, the Center for Epidemiologic Studies Depression Scale, the Spielberger State-Trait Anxiety Inventory, the Anxiety subscale of the Hospital Anxiety and Depression scale and other relevant scales dealing with quality of life assessment among OPs facing RT (1-8, 11, 13-16). A detailed analysis showed that only one study examined the level of fear of RT based on interviews that processes fear of RT and how to deal with the fear of RT (15).

Creating an adequate questionnaire to assess the level of fear of RT would be of great practical importance both in terms of early identification of patients with high levels of fear of RT, and in the strategic planning and timely application of preventive measures in the field of professional psychological support before starting RT with the aim of reducing the fear of RT in OPs. The aim of this study was development, reliability testing and validation of a questionnaire for assessing the level of fear of RT among OPs.

\section{MATERIALS AND METHODS}

We performed a prospective qualitative study based on the development, validation and reliability testing of the questionnaire for assessing RT-caused fear (QAFRT) in OPs. The study lasted 4 months, or until there was an adequate number of respondents. The research was conducted at the Centre for Oncology and Radiology, Clinical Centre Kragujevac, Department of Radiotherapy with the prior approval of the Ethics Committee Clinical Centre Kragujevac.

\section{Population}

The study included all OPs with histopathologically confirmed cancer of any localization and staging of the disease, for whom RT was indicated for the first time and who had been notified and signed an informed consent to participation.

Criteria for inclusion in the study were: patients aged from 18 to 65 years, patients from Serbian-speaking areas, any stage or localization of histologically verified carcinoma, the first time determined treatment of RT. The study included all patients who had voluntarily agreed to participate in the study, who had started treatment RT or applied RT, while radiation therapy was in progress and had completed at least one therapy session, whether as an out-patient or during hospitalization, regardless of whether the radiotherapy was curative or palliative. The criteria for exclusion from the study were: minors and mentally ill patients who were unable to understand the content of the questionnaire adequately.

The variables that were monitored in the study were gender, age, marital status, with whom the patient lives, residence, education, and religiosity. Data related to the disease were obtained by examining the medical records: type of tumor, applied modalities of treatment, comor- 
bidities, type of radiotherapy (curative or palliative), radiotherapy techniques (transcutaneous or intracavitary brachytherapy), localization of the radiation field, the number of radiation fields, the radiation dose, the number of fractions, whether a mask for the head or neck were used, whether there was an explanation of the procedure of radiation, and verbal or written information provided by the radiotherapists.

\section{Power of the study}

It was envisaged that the power of the study would be $80 \%$, based on the probability that there would be a statistical error of type $1(\alpha)$ of 0.05 . In accordance with the formula for calculating the sample size when searching the mean value of a continuous variable in the population, with relevant, literature-based standard deviation measurements $\pm \mathrm{SD}=0.94$ and confidence interval width $\mathrm{d}=$ \pm 0.3 , it was determined that the research would require a minimum of 150 patients (17).

\section{Test procedure}

The decision for treatment with RT was made exclusively by the Council of Oncology. The questionnaire for assessing the level of fear of radiotherapy in OPs and the visual analogue scale (VAS 0-100) were completed independently by the patients after the first session, in the presence of the researcher, and after the fifth session of RT they were filled out by the researcher who asked the patient questions. The process of completing the questionnaire had previously been explained to all the patients.

\section{Creating the questionnaire}

The questionnaire for assessment of fear of radiation therapy in OPs consists of three parts. The first part contains questions related to socio-demographic characteristics. The second part contains information related to the disease. The third part of the questionnaire is related to the patient's fear of RT. Every question, from the last part, has five possible answers according to the Likert scale. The questions were designed based on a review of available literature dealing with this issue and after consultation with the two psychiatrists, seven radiotherapists, two clinical pharmacologists and five senior radiology technicians employed at the Clinical Centre in Kragujevac. The final version of the questions was submitted for consideration to Professor Goran Mihajlovic, a psychiatrist employed at the Clinical Centre in Kragujevac. After obtaining his expert opinion, the final corrections to the questions were made. The questions were listed on the basis of random selection. The last two were trick socially desirable questions. The questionnaire was designed to measure the level of fear in patients after the application of RT. The questionnaire was intended to measure fear of radiation therapy in general. The questions included various aspects of fear of radiation, such as fear of potential side effects after RT exposure, fear of the procedure itself, as well as the possible implications of the type of treatment on the life of the patient after completion of the RT and the course of the disease. The questionnaire is intended for use as a valid instrument for the identification of patients with a high level of fear of RT. Given that in this category of patients fear can be further provoked by other conditions, diseases and treatment options, the results obtained should be evaluated taking into consideration the overall health status of the OP. Patients who show a high level of fear of RT should be referred to a psychologist or psychiatrist, to determine the origin of the fear, prevent serious health consequences and improve the relationship with the patient.

\section{Reliability and validity of the questionnaire}

The internal and external reliability of the questionnaire were tested. The internal consistency all the offered questions was tested and Cronbach $\alpha$ QAFRT's in OPs. Cronbach $\alpha$ may range from 0 to 1 and indicates which answers are consistent to the questions. Account was taken only of Cronbach $\alpha$ values above 0.7 .

Factor analysis was conducted to assess the validity of the content of the questionnaire. The validity of the structure and criterion validity were investigated by testing of the relationship QAFRT and VAS scale. Temporal stability was obtained by comparing answers to the questions of QA-FRT after the first and fifth sessions of RT, or after seven days.

\section{Statistics}

Methods of descriptive statistics were used for sociodemographic and medical records (mean and a standard deviation). Data with normal distribution were analyzed by the parameter Student's T test, while for the data without a normal distribution we used the nonparametric ManWhitney $U$ test. To investigate the frequency of qualitative variables the $\chi^{2}$ test was used. Spearman's coefficient correlations were used to determine the reliability of the questionnaire and its temporal stability. For statistical analysis we used SPSS software, version 18 (Chicago, IL, USA). The difference was considered significant if the probability of the null hypothesis was below 0.05 .

\section{RESULTS}

The study included 154 patients, of which $50 \%$ were men and $50 \%$ women. Thirty-two subjects were excluded from the study pursuant to study protocol violations. The average age of respondents was $62.85 \pm 11.26$ years and the average duration of education $10.05 \pm 3.84$ years. About $55 \%$ of patients had experienced chemotherapy, while $68.2 \%$ of patients had undergone surgery. Curative radiotherapy was conducted in $79.9 \%$ patients while for $20.1 \%$ of patients the radiotherapy was palliative. Only $30.5 \%$ of patients received an explanation from radiotherapists about the therapeutic procedure.

The questionnaire for evaluation of levels of fear of RT initially consisted of 31 items. The answers were coded from 0 to 4 . The final version of the questionnaire has integrated 15 questions. The total score of answers on questions ranging from 0-60. 


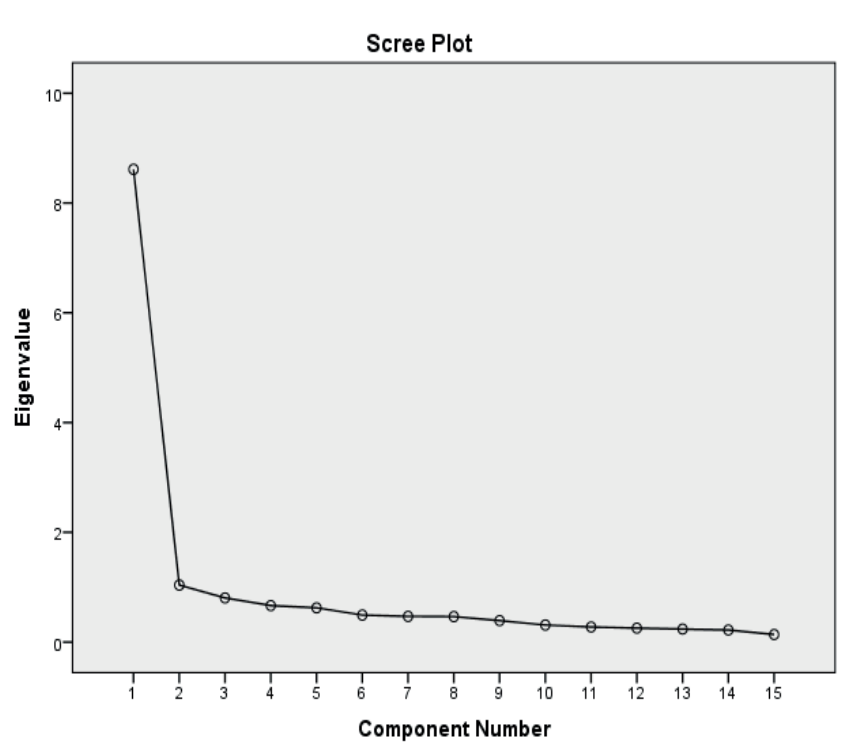

Grafic 1. Scree plot

A correlation matrix was created to determine an adequate connection between the questions. The candidates for elimination were questions whose value correlation coefficient was below 0.2 . It was found that two questions correlated poorly with other matters and were eliminated. The remaining questions correlated appropriately.

The majority of answers to the questionnaire mean value ranged from almost 1 to 1.7 (Table 1). Questions with a low standard deviation, and questions that correlated poorly with the rest of those with similar content, were eliminated from the questionnaire.

Table 1. Mean, standard deviation, skewness, kurtosis and Pearson correlation the questions that make up the final version of the questionnaire

\begin{tabular}{|c|c|c|c|c|c|}
\hline $\begin{array}{l}\text { Number } \\
\text { of issues }\end{array}$ & Mean & $\begin{array}{c}\text { Standard } \\
\text { devia- } \\
\text { tion }\end{array}$ & $\begin{array}{c}\text { Skew- } \\
\text { ness }\end{array}$ & Kurtosis & $\begin{array}{c}\text { Pearson } \\
\text { correla- } \\
\text { tion }\end{array}$ \\
\hline 1. & 1.45 & 1.097 & 0.390 & -0.563 & 0.733 \\
\hline 2. & 1.62 & 1.198 & 0.457 & -0.654 & 0.535 \\
\hline 3. & 1.21 & 1.226 & 0.790 & -0.360 & 0.635 \\
\hline 4. & 1.74 & 1.204 & 0.423 & -0.749 & 0.695 \\
\hline 5. & 1.46 & 1.138 & 0.555 & -0.457 & 0.693 \\
\hline 6. & 1.28 & 1.152 & 0.657 & -0.427 & 0.648 \\
\hline 7. & 1.47 & 1.216 & 0.569 & -0.630 & 0.612 \\
\hline 8. & 1.12 & 1.268 & 0.869 & -0.453 & 0.468 \\
\hline 9. & 1.50 & 1.222 & 0.553 & -0.559 & 0.773 \\
\hline 10. & 0.97 & 1.207 & 1.080 & 0.115 & 0.439 \\
\hline 11. & 1.62 & 1.126 & 0.480 & -0.528 & 0.623 \\
\hline 12. & 1.23 & 1.158 & 0.697 & -0.469 & 0.536 \\
\hline 13. & 1.63 & 1.242 & 0.425 & -0.755 & 0.714 \\
\hline 14. & 1.10 & 1.274 & 0.860 & -0.422 & 0.494 \\
\hline 15. & 1.14 & 1.253 & 0.830 & -0.450 & 0.561 \\
\hline
\end{tabular}

The most important factor for assessing the reliability of the questionnaire as a whole, the coefficient Cronbach $\alpha$ stood at 0.955 . After the elimination of inappropriate questions this was 0.946 .

In order to calculate external reliability, the questionnaire was randomly divided into two parts following the Split-Half models. The value of the Cronbach coefficient for the first part was 0.910 and 0.884 for the second. The coefficients of both parts of the questionnaire amounted to over 0.7 and have a good overall correlation, which contributes to the reliability and integrity of the questionnaire. Predictor reliability, based on the value of the Cronbach coefficient for both parts of the questionnaire, obtained with the help of Spear-man Brown formula, was 0.966.

The correlation of each question with others, was analyzed with the Spearman's coefficient correlation. We set aside two questions that have a value of less than 0.3.

We conducted a factor analysis to determine how many factors were included in the new questionnaire. The Kaiser-Meyer-Olkin test and Bartlett's test of sphericity were determined to be the most appropriate for factor analysis. The values were above 0.5 or 0.932 . It was found that the factor analysis can explore the structure of the questionnaire. The value of $X^{2}$ test amounted to $1584.386(\mathrm{r}=0.000)$.

Given that the eigenvalue was above 1, the questionnaire consists of two factors which represented $57.423 \%$ and $6.925 \%$, making a total of $64.348 \%$ of the variance of the questionnaire. The Graphic 1 - Scree plot shows a clear point of fracture after the second factor. For the first eigenvalue, the factor value was 5.390 , the percentage of variance $35.931 \%$, and the cumulative percentage of variance $35.931 \%$ after Varimax rotation. While the other factor eigenvalue value was 4.263 and the percentage of variance $28.417 \%$, the cumulative percentage of variance amounts to $64.349 \%$.

Table 2. Rotated Component Matrix

\begin{tabular}{|c|c|c|}
\hline \multicolumn{3}{|c|}{ Component } \\
\hline Number of question & 1 & 2 \\
\hline P1 & 0.693 & 0.480 \\
\hline $\mathrm{P} 2$ & 0.180 & 0.830 \\
\hline P3 & 0.770 & 0.340 \\
\hline $\mathrm{P} 4$ & 0.275 & 0.801 \\
\hline P5 & 0.708 & 0.461 \\
\hline P6 & 0.756 & 0.329 \\
\hline P7 & 0.550 & 0.523 \\
\hline P8 & 0.299 & 0.718 \\
\hline P9 & 0.545 & 0.653 \\
\hline $\mathrm{P} 10$ & 0.712 & 0.115 \\
\hline P11 & 0.645 & 0.416 \\
\hline P12 & 0.587 & 0.488 \\
\hline P13 & 0.470 & 0.673 \\
\hline P14 & 0.713 & 0.222 \\
\hline P15 & 0.672 & 0.353 \\
\hline
\end{tabular}


Table 3. Factor and meaning, questions pertaining to factor, Cronbach $\alpha$ and the mean value of the score

\begin{tabular}{|l|l|l|l|}
\hline Factor & Question & $\begin{array}{l}\text { Cronbach } \\
\alpha\end{array}$ & $\begin{array}{l}\text { Median } \\
\text { value } \\
\text { score }\end{array}$ \\
\hline $\begin{array}{l}\text { Factor 1 } \\
\begin{array}{l}\text { Fear of patients related } \\
\text { to the relationship of } \\
\text { family and friends and the } \\
\text { continuation of life after } \\
\text { radiation }\end{array}\end{array}$ & $\begin{array}{l}1,3,5,6,7, \\
14,15\end{array}$ & 0.926 & 12.935 \\
\hline $\begin{array}{l}\text { Factor 2 } \\
\begin{array}{l}\text { Fear linked to } \\
\text { disease prognosis and adverse } \\
\text { effects of radiation }\end{array}\end{array}$ & $2,4,8,9,13$ & 0.881 & 7.628 \\
\hline
\end{tabular}

Table 2 shows the questions based on the weight load belonging to a particular factor after rotation. Name factors with issues, Cronbach coefficient $\alpha$ and a median score are shown in Table 3. List of the questions in final version of the questionnaire for assessing fear of radiotherapy in oncology patients is shown in Table 4.

Convergent validity was investigated in the context of criterion validity. A high degree correlation was found between the VAS scale and recent responses to questions from the QAFRT $(r=0.807, \mathrm{p}=0.000)$, confirming convergent validity.

Table 4. List of questions of final version of The questionnaire for assessment fear of radiotherapy in oncology patients

\begin{tabular}{|c|l|}
\hline 1. & $\begin{array}{l}\text { Do you have a fear that radiation can affect the appearance } \\
\text { of a new tumor? }\end{array}$ \\
\hline 2. & $\begin{array}{l}\text { Are you afraid that radiation therapy can damage other organs, } \\
\text { which are not subjected to radiotherapy? }\end{array}$ \\
\hline 3. & $\begin{array}{l}\text { Do you have a fear that you will endanger your family because } \\
\text { you are in radiation therapy? }\end{array}$ \\
\hline 4. & $\begin{array}{l}\text { Are you afraid that radiotherapy will cause burns at the site } \\
\text { of application of radiation? }\end{array}$ \\
\hline 5. & $\begin{array}{l}\text { Are you afraid that radiation therapy will be hinder your every- } \\
\text { day activities? }\end{array}$ \\
\hline 6. & $\begin{array}{l}\text { Do you have a fear that friends will change their relationship } \\
\text { toward you because you are being treated with radiotherapy? }\end{array}$ \\
\hline 7. & $\begin{array}{l}\text { Were you afraid when you were told that you would continue } \\
\text { the treatment of radiation therapy? }\end{array}$ \\
\hline 8. & $\begin{array}{l}\text { Do you feel disturbed while expecting the application of radio- } \\
\text { therapy? }\end{array}$ \\
\hline 9. & $\begin{array}{l}\text { Are you afraid that radiation therapy can cause permanent } \\
\text { damage to the region of irradiation? }\end{array}$ \\
\hline 15. & $\begin{array}{l}\text { Do you have a fear that you partner will change their relation- } \\
\text { ship toward you because you are being treated with radio- } \\
\text { therapy? }\end{array}$ \\
\hline 11. & $\begin{array}{l}\text { Do you think more often than usual about your illness while on } \\
\text { radiation therapy? }\end{array}$ \\
\hline 12. & $\begin{array}{l}\text { Do you have a fear that radiation therapy will not be effective } \\
\text { against your illness? }\end{array}$ \\
\hline 13. & $\begin{array}{l}\text { Do you have a fear that you have not received all the necessary } \\
\text { information about the potential adverse effects of radiotherapy? }\end{array}$ \\
\hline 14. & $\begin{array}{l}\text { Are you afraid to handle electrical appliances, when you are in } \\
\text { wadiation therapy? }\end{array}$ \\
\hline
\end{tabular}

Temporal stability was tested by correlating the total score responses from QAFRT after the first and fifth session of radiotherapy. Retest after the fifth session of radio-therapy was undertaken by 86 patients. A high correlation between QAFRT scores was determined ( $\mathrm{r}=0.925$, $\mathrm{p}=0.000$ ), which indicates good temporal stability.

\section{DISCUSSION}

The results of the study confirm that the QAFRT in OPs is a reliable and valid instrument for measuring the level of fear of RT. The questionnaire consists of 15 questions and has a good coexistence of internal structure which is summarized in two factors. The identified factors were: "fear related to the attitude of family and friends and the continuation of life after irradiation", and "fear factor related to the prognosis of the disease and the side effects of RT". The Cronbach coefficient $\alpha(0.946)$ confirmed the reliability of the questionnaire. Since the Cronbach coefficient before correction issues had a high value (0.952), 16 questions with similar content and with insufficient criteria for questionnaire inclusion were removed. A shorter version of the questionnaire was then drafted with a somewhat lower Cronbach coefficient (0.946). The criterion validity of the questionnaire was confirmed by examination of convergent validity with the VAS scale. The new questionnaire has also shown exceptional temporal stability and test-retest reliability. In the methodological development of the questionnaire, participants were interviewed in two ways, because this was part of the validation procedure. The good correlation which was achieved between the two tests proved that the questionnaire was valid for use.

The first factor called "fear of patients related to the attitude of family and friends and the continuation of life after irradiation" and composed of 10 questions, confirmed high internal coexistence (Cronbach $\alpha$ 0.926). This factor accounted for $35.931 \%$ of the variability of the questionnaire. Questions related to the patients fear during and/ or after RT such as changing family relationships, partners and friends, fear connected to daily activities and life after completing treatment.

In the study conducted by Sundaresan and associates, it was observed that more than half of the patients were concerned about the possible impact of RT on family life, living and working obligations and the later effects of radiation (10). Turner and contributors also confirmed that patients in the course of implementation of RT were concerned for their family and the future (12).

The second factor "fear linked to disease prognosis and the adverse effects of radiation" was formed in five questions. The value of the Cronbach coefficient $\alpha$ for this factor was 0.881 and explained $64.349 \%$ of the variance. The questions included in this factor related to the fear of patients' lack of necessary information about the potential adverse effects of RT, fear of disease progression and damage to other organs, as well as the fear of the radiation procedure itself. 
Fear in patients can be a major obstacle to the implementation of the prescribed treatment (17). Earlier studies showed that 10 to $20 \%$ of the patients feel anxiety before the start of the RT, and that $20-50 \%$ of patients are anxious during the first day of RT. Fear and anxiety are commonly associated with a lack of information, side effects of treatment and the radiation procedure $(2,5,10,17)$. Sehlen and contributors found that most patients are afraid of the possible side effects of radiation (18). In order to avoid additional psychological and physical stress, in these vulnerable categories of patients, it is necessary to organize screening at the beginning of RT treatment that would allow identification of patients with increased risk of mental instability during treatment (19). The ideal would be to separate risk patients for radiotherapy simulation, or before starting radiation (17).

Our study had several limitations: it was conducted in a single centre, and the test-retest reliability assessment was carried out after seven days. In addition divergent stability was not examined. The majority of respondents were older and less educated, so the reliability of the questionnaire should also be examined in the other categories of patients. Also, it was not possible to ensure the presence of a psychiatrist and an overview of each participant after examination or to compare his findings with the results of responses to the questionnaire. The reliability of the questionnaire should be examined after an extended time period after completion of RT treatment, and the results compared with the results of our study. It is possible that the level of fear in the same patient changes over time and decreases as the therapy nears completion. There is no relevant questionnaire that measures the level of fear of radiotherapy with which we can compare our results.

The results of our study show that the used questionnaire was a unique, reliable and valid instrument for assessing the level of fear of RT in OPs, the application of which makes it possible to identify patients with elevated levels of fear of RT. Patients with a high total score would require special attention and adequate psychological or psychiatric support, with a maximum reduction of adverse events, allowing the treatment to be implemented fully and adequately.

\section{Acknowledgements}

The authors are grateful to Professor Goran Mihajlovic, a psychiatrist employed in the Clinical Centre in Kragujevac and Faculty of Medical Sciences, University of Kragujevac, for expert assistance during the making of the final version of the questionnaire.

\section{REFERENCES}

1. Andersen BL, Tewfik HH. Psychological reactions to radiation therapy: reconsideration of the adaptive aspects of anxiety. J Pers Soc Psychol 1985;48(4):1024-32.

2. Peck A, Boland J. Emotional reactions to radiation treatment. Cancer 1977;40(1):180-4.
3. Krischer MM, Xu P, Meade CD, Jacobsen PB. Self-administered stress management training in pa-tients undergoing radiotherapy. J Clin Oncol 2007;25(29):4657-62.

4. Braeken AP, Kempen GI, Eekers DB, et al. Psychosocial screening ef-fects on health-related outcomes in patients receiving radiotherapy. A cluster randomised controlled trial. Psychooncology 2013; 22(12):2736-46.

5. Halkett GK, Kristjanson LJ, Lobb EA. 'If we get too close to your bones they'll go brittle': women's initial fears about radiotherapy for early breast cancer. Psychooncology 2008;17(9):877-84.

6. Siekkinen M, Pyrhönen S, Ryhänen A, Vahlberg T, Leino-Kilpi H. Psychosocial outcomes of e-feedback of radiotherapy for breast cancer patients: a randomized controlled trial. Psychooncology 2015;24(5):515-22.

7. Timmermans LM, van der Maazen RW, Leer JW, Kraaimaat FW. Palliative or curative treatment intent affects communication in radiation therapy consultations. Psychooncology 2006;15(8):713-25.

8. Cieślak K, Pawlukiewicz M, Gołąb D, Konys M, Kuśnierkiewicz M, Kleka P. Styles of coping with stress of cancer in patients treated with radiotherapy and expectations towards medical staff - Practical implications. Rep Pract Oncol Radiother 2012;18(2):61-6.

9. Gillespie SM, Mitchell IJ, Satherley RM, Beech AR, Rot-shtein P. Relations of Distinct Psychopathic Personality Traits with Anxiety and Fear: Findings from Offenders and Non-Offenders. PLoS One 2015;10(11):e0143120.

10. Sundaresan P, King MT, Stockler MR, Costa DS, Milross CG. Barriers to radiotherapy utilisation in New South Wales Australia: Health professionals'perceptions of impacting factors. J Med Imaging Radiat Oncol 2015;59(4):535-41.

11. Schofield P, Gough K, Ugalde A, Carey M, Aranda S, Sanson-Fisher R. Cancer Treatment Survey (CaTS): development and validation of a new instrument to measure patients' preparation for chemotherapy and radiotherapy. Psychooncology 2012;21(3):307-15.

12. Turner NJ, Muers MF, Haward RA, Mulley GP. Psychological distress and concerns of elderly patients treated with palliative radiotherapy for lung cancer. Psychooncology 2007;16(8):707-13.

13. Arraras JI, Rico M, Vila M, Chicata V, Asin G, Martinez $\mathrm{M}$, et al. The EORTC cancer outpatient satisfaction with care questionnaire in ambulatory radiotherapy: EORTC OUT-PATSAT35 RT. Validation study for Spanish patients. Psychooncology 2010;19(6):657-64.

14. Timmermans LM, van Zuuren FJ, van der Maazen RW, Leer JW, Kraaimaat FW. Monitoring and blunting in palliative and curative radiotherapy consultations. Psychooncology. 2007;16(12):1111-20.

15. Halkett GK, Kristjanson LJ, Lobb E, Little J, Shaw T, Taylor $\mathrm{M}$, et al. Information needs and preferences of women as they proceed through radiotherapy for breast cancer. Patient Educ Couns. 2012;86(3):396-404. 
16. Piderman KM, Johnson ME, Frost MH, Atherton PJ, Satele DV, Clark MM et al. Spiritual quality of life in advanced cancer patients receiving radiation therapy. Psychooncology 2014;23(2):216-21.

17. Lewis F, Merckaert I, Liénard A, Libert Y, Etienne AM, Reynaert C. Anxiety and its time courses during radiotherapy for non-metastatic breast cancer: A longitudinal study. Radiotherapy and Oncology 2014;111:276-80.
18. Sehlen S, Fahmüller H, Herschbach P, Aydemir U, Lenk M, Dühmke E. Psychometric properties of the Stress Index Radio Oncology (SIRO)--a new questionnaire measuring quality of life of cancer patients during radiotherapy. Strahlenther Onkol 2003;179(4):261-9.

19. Sostaric M, Sprah L. Psychological distress and intervention in cancer patients treated with radiotherapy. Radiol Oncol 2004; 38(3):193-203. 